\title{
Correction to: The Importance of the Neighbourhood Environment and Social Capital for Happiness in a Vulnerable District: The Case of the Pajarillos District in Spain
}

\author{
Noelia Somarriba Arechavala ${ }^{1}$ (D) . Pilar Zarzosa Espina ${ }^{2}$ (D) \\ Ana Teresa López Pastor ${ }^{3}$ \\ Published online: 11 February 2022 \\ (c) Springer Nature B.V. 2022
}

\section{Correction to: Journal of Happiness Studies https://doi.org/10.1007/s10902-021-00479-x}

In the original publication, the affiliation of authors has been published incorrectly. The correct affiliation is given in this correction.

Publisher's Note Springer Nature remains neutral with regard to jurisdictional claims in published maps and institutional affiliations.

The original article can be found online at https://doi.org/10.1007/s10902-021-00479-x.

Noelia Somarriba Arechavala

marianoelia.somarriba@uva.es

Pilar Zarzosa Espina

pilar.zarzosa@uva.es

Ana Teresa López Pastor

anateresa.lopez@uva.es

1 Department of Applied Economy, Faculty of Social, Communication and Legal Sciences, University of Valladolid, Segovia, Spain

2 Department of Applied Economy, Faculty of Economics, University of Valladolid, Valladolid, Spain

3 Department of Sociology, Faculty of Social, Communication and Legal Sciences, University of Valladolid, Segovia, Spain 